\title{
Rheology of High Volume Sidoarjo Mud Mortar
}

\section{Teguh Hermawan Widodo ${ }^{1 a}$, Lucky Chandra ${ }^{1 b}$, Antoni $^{2 c}$, Djwantoro Hardjito ${ }^{2 \mathrm{~d}}$}

\author{
${ }^{1}$ Postgraduate program in Civil Engineering, Petra Christian University, Jalan Siwalankerto 121- \\ 131, Surabaya 60236, Indonesia \\ ${ }^{2}$ Department of Civil Engineering, Petra Christian University, Jalan Siwalankerto 121-131, \\ Surabaya 60236, Indonesia
}

awan_wan_widodo@yahoo.com, blucky.chandra1992@gmail.com, cantoni@petra.ac.id, djwantoro.h@petra.ac.id

\author{
Keywords : Sidoarjo Volcanic Mud, High Volume Cement Replacement, Rheology, Flow, \\ Fineness
}

\begin{abstract}
Previous studies on Sidoarjo volcanic mud have been largely focusing on its use as lowvolume cement replacement pozzolanic material and not as a high-volume cement replacement material. This study is intended to study the behaviour of fresh mortar incorporating Sidoarjo volcanic mud as cement replacement in high-volume i.e. 50\%, 55\% and 60\%; and compares the results with the ones of high-volume fly ash mortar. Calcination and grinding were applied as pretreatment for the mud to make it more reactive. Grinding time was varied into three different grinding time periods from two to eight hours, to vary the particle sizes of the calcined mud. The results show that the finer the particle size of the Sidoarjo volcanic mud, the bigger the flow of the fresh mortar. The flow of fresh mortar containing the Sidoarjo mud is lower compared to those of the ones with fly ash.
\end{abstract}

\section{Introduction}

Sidoarjo mud volcano eruption disaster has been taking place since May 2006, causing a substantially negative impact to the surrounding population in the sectors of economy, social and many more. Various attempts have been made to cope with the disaster but to no avail. The existence of large amount of mud, in which the eruption was started in Ronokenongo Village of Porong County in Sidoarjo Regency, has halted daily activities of local people as their villages have been covered by meters of thick mud.

Previous research [1-3] have used Sidoarjo mud - after calcination treatment process and using bar-mill to achieve certain level of fineness - as a pozzolanic material. The mud content were of $30 \%, 40 \%$ and $50 \%$ of the total binder, and the mortar was tested at the age up to 56 days. The results show that the finer the particle size of Sidoarjo mud is, the higher the compressive strength of the mortar produced. Replacing $30 \%$ of the cement content with the treated Sidoarjo mud was found to be the most effective. However, 35\% and $40 \%$ mud content can still be used because it meets the minimum level of Strength Activity Index (SAI) required [4]. SAI is a comparison of the value of the compressive strength of concrete or mortar mix using pozzolanic material with the ones without using any pozzolan. In workability, the finer the particle size and the higher the replacement percentage of the mud, the bigger the flow of the fresh mortar produced.

In our previous study [3], we found that Sidoarjo volcanic mud can be used in more than $40 \%$ replacement of the total binder, while maintaining high SAI. In that study, the content of Sidoarjo volcanic mud was varied - in a high volume -, i.e. from $50 \%$, to $60 \%$. At the same time, the particle size of the calcined Sidoarjo mud was also varied. Variation in particle size was achieved by varying the grinding time from two to eight hours. The particle size was also ensured to be less than $63 \mu \mathrm{m}$. All of these all were investigated its potential to produce high volume Sidoarjo mud mortar.

While the previous report is more on the mechanical properties of harden high volume Sidoarjo mud mortar, this paper focusses more on the rheology of the fresh state mortar, as measured by its flow properties, as well as its setting time. 


\section{Materials and Method}

The treatments for the fresh Sidoarjo mud material were conducted in several stages, starting from moulding, drying, calcination and then grinding with specified time period. The fresh mud was molded into brick form, and then dried to reduce its water content. Drying process was performed to reduce the smoke during the calcination. Calcination process was conducted with gradual increase of temperature up to its peak at $945^{\circ} \mathrm{C}$. The calcination temperature was kept constant for 5 hours, followed by cooling process for about 36 hours, before the material was taken out from the calcination chamber. Calcination was carried out at a local roof tile manufacturer facility.

The next treatment process was using bar-mill to grind the calcined mud from two to eight hours. Differences in grinding time resulted in variation of fine particle sizes produced. Grinding process was conducted using a steel drum with steel bars inside, rotated at a constant rate. It should be noted that the particle size of the calcined mud was ensured to be smaller than $63 \mu \mathrm{m}$.

Characterizations of the treated Sidoarjo volcanic mud were performed by using the Particle Size Analysis (PSA) and the X-Ray Flouresence (XRF). Sand was characterized for its water content, fineness modulus, and gradation.

The mixture proportion of the mortar was divided into 3 different variatons, i.e. mortar without any pozzolanic material, high volume class $\mathrm{F}$ fly ash mortar, and high volume Sidoarjo volcanic mud mortar, whereby the water/cementitious ratio was kept constant at 0.35 , as can be seen in Table 1. Fly ash was obtained from a power plant located in Paiton, East Java, Indonesia. Pozzolan content is determined as the ratio between the mass of pozzolan and the total mass of cementitious material (pozolan plus Portland cement). The size of the mortar is $5 \times 5 \times 5 \mathrm{~cm}^{3}$ cube. Superplasticiser was added to improve the workability, in term of percentage, by mass, of the cementitious material.

Table 1: Mixture Proportion

\begin{tabular}{ccccccc}
\hline $\begin{array}{c}\text { Pozzolan } \\
\text { Type }\end{array}$ & $\begin{array}{c}\text { Pozzolan } \\
\text { Content }(\mathbf{\%})\end{array}$ & $\begin{array}{c}\text { Cement } \\
\left(\mathbf{k g} / \mathbf{m}^{\mathbf{3}}\right)\end{array}$ & $\begin{array}{c}\text { Pozzolan } \\
\left(\mathbf{k g} / \mathbf{m}^{\mathbf{3}}\right)\end{array}$ & $\begin{array}{c}\text { Sand } \\
\left(\mathbf{k g} / \mathbf{m}^{\mathbf{3}}\right)\end{array}$ & $\begin{array}{c}\text { Water } \\
\left(\mathbf{l i t e r} / \mathbf{m}^{\mathbf{3}}\right)\end{array}$ & $\begin{array}{c}\text { Superplasticizer } \\
(\mathbf{\%} \mathbf{m} \mathbf{~ c m})\end{array}$ \\
\hline $\begin{array}{c}\text { Without } \\
\text { Pozzolan }\end{array}$ & - & 660 & - & 1509 & 231 & 1.5 \\
\hline & 50 & 330 & 330 & 1509 & 231 & 0.050 \\
Fly ash & 55 & 270 & 390 & 1509 & 231 & 0.041 \\
& 60 & 240 & 420 & 1509 & 231 & 0.036 \\
\hline Sidoarjo & 50 & 330 & 330 & 1509 & 231 & 1.5 \\
Volcanic & 55 & 270 & 390 & 1509 & 231 & 1.5 \\
$\quad$ Mud & 60 & 240 & 420 & 1509 & 231 & 1.5 \\
\hline
\end{tabular}

\section{Results and Discussion}

XRF Analysis and PSA. XRF analysis was employed to determine the oxides composition of Sidoarjo volcanic mud and fly ash. Based on the results of XRF analysis, Sidoarjo mud has been qualified as a pozzolanic material, since it has a total mass percentage of $\mathrm{SiO}_{2}, \mathrm{Fe}_{2} \mathrm{O}_{3}$, and $\mathrm{Al}_{2} \mathrm{O}_{3}$ of larger than $70 \%$. In comparison with the previous studies, the content of the Sidoarjo mud sample in this study resembles the ones reported in 2010 [5], as shown in Table 2:

Table 2: XRF Analysis Results of Sidoarjo Volcanic Mud and Fly Ash (\% by mass)

\begin{tabular}{cccccccccccc}
\hline Oxide & $\mathbf{C a O}$ & $\mathbf{S i O}_{2}$ & $\mathbf{A l}_{\mathbf{2}} \mathbf{O}_{\mathbf{3}}$ & $\mathbf{F e}_{\mathbf{2}} \mathbf{O}_{\mathbf{3}}$ & $\mathbf{K}_{\mathbf{2}} \mathbf{O}$ & $\mathbf{M g O}$ & $\mathbf{S O}_{3}$ & $\mathbf{M n O}_{2}$ & $\mathbf{T i O}_{\mathbf{2}}$ & $\mathbf{C r}_{2} \mathrm{O}_{3}$ & $\mathbf{N a}_{2} \mathbf{O}$ \\
\hline $\mathbf{1}$ & 4.90 & 54.90 & 20.44 & 10.64 & 2.35 & 1.76 & 1.31 & 0.21 & 1.16 & 0 & 0 \\
$\mathbf{2}$ & 2.13 & 56.75 & 23.31 & 7.37 & 1.04 & 2.95 & 0.96 & 0.14 & 0.38 & 0.01 & 2.70 \\
$\mathbf{3}$ & 4.49 & 52.12 & 25.64 & 9.84 & 1.17 & 2.89 & 0 & 0.10 & 0.96 & 0.02 & 0.71 \\
\hline
\end{tabular}

Source: $\quad$ 1. Sidoarjo volcanic mud 2010 [5]

2. Sidoarjo volcanic mud sample in this research

3. Fly ash from Paiton power plan 
Table 3 shows the results obtained from the particle size analysis (PSA). Prolong the grinding time resulted in finer particle size and subsequently increases the specific surface area (SSA). It is to be noted that before PSA was performed, the mud particles bigger than $63 \mu \mathrm{m}$ was removed. Increase in SSA is expected to improve the reactivity of the material.

Table 3: Particle Size Analysis Results

\begin{tabular}{cccc}
$\begin{array}{c}\text { Grinding Time } \\
\text { (hours) }\end{array}$ & $\begin{array}{c}\mathbf{d}(\mathbf{1 0}) \\
(\boldsymbol{\mu m})\end{array}$ & $\begin{array}{c}\mathbf{d}(\mathbf{5 0}) \\
(\boldsymbol{\mu m})\end{array}$ & $\begin{array}{c}\text { SSA } \\
\left(\mathbf{m}^{\mathbf{2}} / \mathbf{g}\right)\end{array}$ \\
\hline $\mathbf{2}$ hours & 1.832 & 15.180 & 1.30 \\
$\mathbf{4}$ hours & 0.937 & 7.991 & 2.24 \\
$\mathbf{8}$ hours & 0.768 & 6.632 & 2.58 \\
\hline
\end{tabular}

Effect of the Sidoarjo Volcanic Mud Content and Fineness on Mortar Workability. The workability tests were conducted on fresh mortar with various calcined mud content and fineness by using the flow table apparatus. Flow is defined as the difference between the final and the initial diameters. Table 4 summarizes the test results.

Table 4: Flow Table Test Results

\begin{tabular}{cccccc}
\hline $\begin{array}{c}\text { Pozzolan } \\
\text { Type }\end{array}$ & $\begin{array}{c}\text { Grinding } \\
\text { Time }\end{array}$ & $\begin{array}{c}\text { Pozzolan } \\
\text { Content } \\
\mathbf{( \% )}\end{array}$ & $\begin{array}{c}\text { Initial } \\
\text { Diameter }\end{array}$ & $\begin{array}{c}\text { Final } \\
\text { Diameter }\end{array}$ & Flow \\
\hline No Mud & (hours) & $\mathbf{( m m )}$ & (mm) & $\mathbf{( m m )}$ \\
\hline \multirow{3}{*}{ Fly ash } & - & & 101.9 & 130.6 & 28.7 \\
\hline & & 50 & 103.5 & 148.4 & 44.9 \\
& & 55 & 104.6 & 156.0 & 51.4 \\
& & 60 & 106.1 & 158.5 & 52.4 \\
\cline { 2 - 6 } Sidoarjo & 4 hours & 50 & 102.1 & 116.3 & 14.2 \\
Volcanic & & 55 & 102.9 & 120.7 & 17.8 \\
Mud & & 60 & 101.9 & 112.3 & 10.4 \\
\cline { 2 - 6 } & & 50 & 103.5 & 121.1 & 17.6 \\
& & 55 & 102.4 & 125.4 & 23.0 \\
& & 60 & 103.4 & 124.5 & 21.1 \\
\hline
\end{tabular}

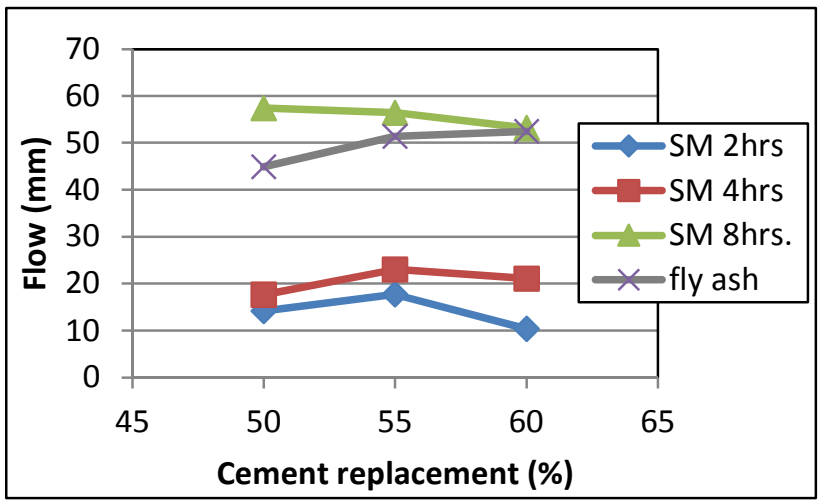

(a)

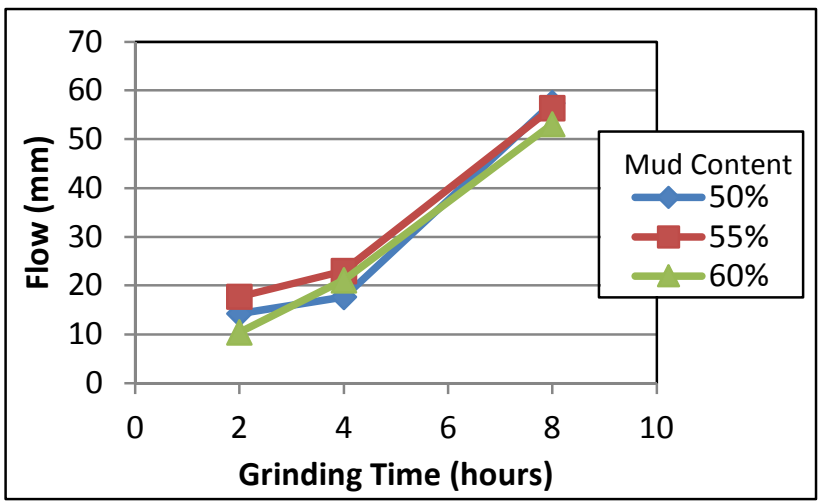

(b)

Fig. 1: (a).The Influence of Pozolan Content on Flow of Fresh Mortar; (b). The Influence of Fineness of Calcined Sidoarjo Mud on Flow of Fresh Mortar 
Fig. 1 shows that among the high volume Sidoarjo mud mortar, the largest flow value was achieved by the one incorporating calcined mud with 8 hours grinding time, with a percentage of pozzolan of $50 \%$. In between $50-60 \%$, the variation of pozzolan content does not significantly affect the mortar flow value. As mentioned earlier, longer grinding time produces finer particle size of calcined mud. Opposite to what was expected before, the finer the particle size of the Sidoarjo mud used, the higher is the flow value of the fresh mortar. It is to be noted that the particle shape of the calcined Sidoarjo mud is irregular. This phenomenon is still under on-going study.

In comparison with fresh mortar using no pozzolanic material, the flow of mortar incorporating Sidoarjo calcined mud is significantly higher. However, compared to the ones of class $F$ fly ash mortar, the flow of high volume Sidoarjo mud mortar with 8 hours grinding time is similar only after the addition of $1.5 \%$ superplasticizer. Fly ash is well known with its spherical shape, which improves the workability.

Influence of the Pozzolan Content and Fineness of the Sidoarjo Volcanic Mud on the Mortar Setting Time. The setting time testing for mortar was performed by using pocket penetrometer for the initial setting time, and pump penetrometer for the final setting time. Test was carried out for every mixtures with various level of pozzolan type, content and fineness.

Table 5 shows the setting times of high volume pozzolan mortar. Designation FA50 denotes high volume fly ash mortar with fly ash content of $50 \%$ of the total mass of cementitious material. On the other hand, SM50 indicates high volume Sidoarjo mud (SM) with the mud content of 50\%, while G2 designates the grinding time of two hours. SM60G8 specifies high volume Sidoarjo mud (SM) mortar with $60 \%$ mud content and eight hours grinding time, which means that the calcined mud used was the one with the finest particle size.

Initial setting times of high volume Sidoarjo mud mortar tend to be shorter when the content of the mud is increased. The same trend is shown by the final setting time. On the other hand, the finer the particle size of the calcined mud, the longer the initial setting time. It seems that the final setting time does not vary with the particle size of the calcined mud.

In comparison with the setting time of high volume class $\mathrm{F}$ fly ash mortar, setting times of high volume Sidoarjo mud mortar are significantly shorter, except for the ones of finest particle size. Fly ash is known to cause longer setting time and slower strength development when incorporated into the making of mortar or concrete as partial substitute for cement.

Table 5: Setting Time of High Volume Pozzolan Mortar

\begin{tabular}{ccc}
\hline \multirow{2}{*}{ Mortar } & \multicolumn{2}{c}{$\begin{array}{c}\text { Setting Time } \\
\text { (minutes) }\end{array}$} \\
\cline { 2 - 3 } & Initial & Final \\
\hline FA50 & 280 & 450 \\
FA55 & 340 & 555 \\
FA60 & 340 & 575 \\
\hline SM50G2 & 90 & 410 \\
SM55G2 & 130 & 450 \\
SM60G2 & 123 & 412 \\
\hline SM50G4 & 220 & 470 \\
SM55G4 & 125 & 400 \\
SM60G4 & 120 & 370 \\
\hline SM50G8 & 355 & 470 \\
SM55G8 & 320 & 445 \\
SM60G8 & 275 & 408 \\
\hline
\end{tabular}

Influence of Pozzolan Content, Type and Fineness of Sidoarjo Volcanic Mud on the Compressive Strength of Mortar. The compressive strength tests of mortar was conducted by using a Universal Testing Machine at the age of samples of 7 days, 14 days, 28 days, and 56 days. Each data represents the mean of compressive strengths of three cube specimens. Strength Activity 
Index (SAI) is a measure of the pozzolanic activity of a pozzolanic material. It was measured as the ratio of compressive strength of mortar incorporating pozzolan with the one with $100 \%$ cement, while the other mixture compositions were kept constant. SAI is expected to be higher than $75 \%$.

It was found that the use of volcanic mud content of $50-60 \%$ is possible to produce high volume Sidoarjo mud mortar with very high SAI, especially the ones with the fines particle size produced after 8 hours grinding time. The finer the particle size of calcined mud, the higher the compressive strength of the mortar. When the calcined Sidoarjo mud content was increased from $50-60 \%$, the SAI was reduced. However, for the calcined mud obtained after 8 hours grinding time with specific surface area (SSA) of $2.58 \mathrm{~m}^{2} / \mathrm{g}$, the SAI is always very high since from 7-day of age, i.e. higher than $85 \%$.

Table 6: Compressive Strength of Mortar and SAI Values

\begin{tabular}{ccccccccc}
\hline Ages & \multicolumn{2}{c}{ 7 days } & \multicolumn{2}{c}{ 14 days } & \multicolumn{2}{c}{ 28 days } & \multicolumn{2}{c}{ 56 days } \\
\hline & $\mathbf{( M P a )}$ & SAI \% & $\mathbf{( M P a )}$ & SAI \% & (MPa) & SAI \% & (MPa) & SAI \% \\
\hline No mud & 42.00 & 100.00 & 51.73 & 100.00 & 52.00 & 100.00 & 54.67 & 100.00 \\
\hline FA50 & 25.30 & 60.24 & 36.00 & 69.59 & 43.33 & 83.33 & 43.47 & 79.51 \\
FA55 & 28.67 & 68.26 & 36.13 & 69.84 & 43.20 & 83.08 & 43.73 & 79.99 \\
FA60 & 27.33 & 65.07 & 31.73 & 61.34 & 42.60 & 81.92 & 43.60 & 79.75 \\
\hline SM50G2 & 29.07 & 69.21 & 36.13 & 69.84 & 39.33 & 75.63 & 44.13 & 80.72 \\
SM55G2 & 26.93 & 64.12 & 33.60 & 64.95 & 37.60 & 72.31 & 42.53 & 77.79 \\
SM60G2 & 26.27 & 62.55 & 35.07 & 67.79 & 37.47 & 72.06 & 41.60 & 76.09 \\
\hline SM50G4 & 31.47 & 74.93 & 37.73 & 72.94 & 46.80 & 90.00 & 52.67 & 96.34 \\
SM55G4 & 29.60 & 70.48 & 35.07 & 67.79 & 44.80 & 86.15 & 49.47 & 90.49 \\
SM60G4 & 29.07 & 69.21 & 31.20 & 60.31 & 39.60 & 76.15 & 41.07 & 75.12 \\
\hline SM50G8 & 40.40 & 96.19 & 47.73 & 92.27 & 50.80 & 97.69 & 52.20 & 95.48 \\
SM55G8 & 36.53 & 86.98 & 44.67 & 86.35 & 45.60 & 87.69 & 50.27 & 91.95 \\
SM60G8 & 37.73 & 89.83 & 43.07 & 83.26 & 45.20 & 86.92 & 49.47 & 90.49 \\
\hline
\end{tabular}

Based on data displayed in Table 6, it can be seen that the value of SAI of the high volume Sidoarjo mud mortar with 4 hours grinding time, with SSA of $2.24 \mathrm{~m}^{2} / \mathrm{g}$, are more than $75 \%$ at the age of 28-day and beyond. However, the coarser Sidoarjo mud obtained after 2 hours grinding time with SSA of $1.30 \mathrm{~m}^{2} / \mathrm{g}$ indicates its low pozzolanic reactivity, shown by its low SAI. To conclude, the calcined Sidoarjo mud with SSA of $2.58 \mathrm{~m}^{2} / \mathrm{g}$ or bigger is a good candidate for making high volume pozzolan mortar with very high SAI since from its early age.

\section{Conclusion}

The following conclusions can be drawn from the present study:

1. The finer the particle size of the calcined Sidoarjo volcanic mud tends to cause the bigger flow of high volume Sidoarjo volcanic mud mortar.

2. The setting times of high volume Sidoarjo volcanic mud mortar tends to be faster compared to the ones of high volume fly ash mortar. In which, the lower the percentage and the smaller the particle size of Sidoarjo volcanic mud are, the longer the duration of setting time will be.

3. The calcined Sidoarjo volcanic mud, with SSA of $2.58 \mathrm{~m}^{2} / \mathrm{g}$ or bigger, can be utilized to produce high volume pozzolan mortar with SAI values of more than $85 \%$ since from its early age.

\section{Acknowledgements}

This work was financially supported by The Directorate General for Higher Education, Ministry of Education and Culture, Indonesia, under the Decentralized Competitive Research Grant Scheme AUPT 2012-2013 and The Centralized Competitive Research Grant HIKOM in 2014. 


\section{References}

[1] Antoni, D. Hardjito, F. Wibowo, and N. W. Chandra, "Influence of Heat Treatment Temperature, Particle Fineness and Replacement Ratio of Sidoarjo Mud as Pozzolanic Material," Proceeding of The $5^{\text {th }}$ International Conference of Asian Concrete Federation, Pattaya, Thailand, 24-26 October 2012

[2] D. Hardjito, G. M. Wibowo, and D. Christianto, "Pozzolanic Activity Assessment of LUSI (LUmpur SIdoarjo) Mud in Semi High Volume Pozzolanic Mortar,” Materials, vol. 5, no. 9, pp. 1654-1660, Sep. 2012.

[3] Antoni, D. Hardjito, L. Chandra, and T. H. Widodo, "On the Development of High Volume Volcanic Mud," Proceeding of the $13^{\text {th }}$ EASEC Conference on Structural Engineering and Construction, Sapporo, Japan, September 11-13, 2013.

[4] ASTM C 618-03, Standard Specification for Coal Fly Ash and Raw or Calcined Natural Pozzolan for Use in Concrete. 2003: ASTM International.

[5] T. R. Nuruddin, M. F., Bayuaji, R., Masilamani, M. B., \& Biyanto, "Sidoarjo Mud : A Potential Cement Replacement Material," Civil Engineering Dimension., vol. 12, no. 1, pp. 18-22, 2010. 
Geopolymer and Green Technology Materials

10.4028/www.scientific.net/MSF.803

Rheology of High Volume Sidoarjo Mud Mortar

10.4028/www.scientific.net/MSF.803.160 